\title{
THE MODERN STATE OF ENTERPRISE INNOVATION ACTIVITY IN KAZAKHSTAN
}

Nurlan Kurmanov ${ }^{1}$, Dina Aibosynova ${ }^{2}$

Abstract: In the XXI century, the key to rapid socio-economic development is to have an effective innovation policy, aimed at introducing high "disruptive" technologies, new ways to organise and manage work, advanced inventions, and the means to progress scientific and technical achievements.

The formation of an innovative economy in Kazakhstan is a complexity of economic, social, and political issues. An effective use of research findings and developments in the real economy is most important in terms of Kazakhstan's successful competitiveness, assurance for high economic growth, improved quality of life, and to help realize other innovative priorities. In these circumstances, innovation management and development is becoming more relevant as the basis for developing Kazakh companies, by way of a defined set of relevant technical, operational, organizational, marketing, and financial operations.

The purpose of this study is to identify characteristics and practical recommendations for the development and further improvement of management mechanisms relating to the innovative activity of enterprises in Kazakhstan. The study used a systematic approach of comparison, scientific abstraction, data collection, analysis and synthesis, applied expertise, and statistical methods. The core value of the work was to support the feasibility of a system for Kazakh enterprises to promote innovative activity and the development of high technologies.

UDC Classification: 33:001.895, DOI: http://dx.doi.org/10.12955/cbup.v3.594

Keywords: innovation, innovation process, enterprise innovative activity, commercialization of technologies, demand for innovation.

\section{Literature Review}

Many economists and practitioners focus their attention on the scientific support of innovation management in the economic and social spheres. Individual theoretical and practical aspects are considered in the works of Koshanov (2012), Dnishev (2012), Saktaganova (2011), Nurlanova (2011) Yvitsa (2012), and others. They are also the subject of intense debate at international and national universities, scientific conferences, symposiums, congresses, and seminars, including the Astana Economic Forum (2012), the Aktobe Regional State University (2011), and the Eurasion National University (2011), among others. However, a significant number of scientific issues that are related to effective state management of innovative processes within the economy, remain outstanding in the context of Kazakhstan.

\section{Introduction}

The main research objectives are to elucidate the participation level and influence of the state on processes occurring in the economy, and to find ways to further develop the economy, including alternative bases. An analysis of foreign experience has found that the most important factors for ensuring economic progress through innovation, are high-quality education and health care, which contribute to human capital. Based on these factors, countries like Canada, France, Sweden, and Finland, for example, have achieved significant results. In the United States, Japan, Germany, and Switzerland, the most important factors have been the quality of scientific organizations, and their ability to work with businesses and focus on the commercialization of their results, as well as matters of corporate management and ethical business. Compared to the developed countries, Singapore, Malaysia, South Korea, and China have focused their attention on global industrial development, the prevalence of which is typical for other developing countries.

\footnotetext{
${ }^{1}$ Nurlan Kurmanov PhD, Associate professor, Kazakh University of Economics, Finance and International Trade, n.a.kurman@mail.ru

${ }^{2}$ Dina Aibosynova, PhD student, L.N. Gumilyov Eurasian National University, Republic of Kazakhstan, dinaastana@mail.ru
} 
In Kazakhstan, as with other economically-developing countries, the need for innovative development has been mainly initiated by the state. In 1997, the conceptual underpinnings for an innovative orientation of the economy was proposed in the 2030 Development Strategy of Kazakhstan, in an address by the President of the Republic of Kazakhstan, N. Nazarbayev to the nation (Nazarbayev, 1997). Questions thereafter were addressed time and again, directly or indirectly, by the President in annual addresses to the nation of Kazakhstan and other speeches (Nazarbayev, 2005; Nazarbayev 2012, January 28; Nazarbayev, 2012, September 6). The focus on accelerating the development of primary industries was the only possibility to overcome costs of a transformational crisis in the late 90s. The approach in economic management, itself, was based on the principles of strategic planning, and innovative forecasting. The determination of a long-term development strategy of the state was based on emphasized priorities. This paid off because provided the national economy with a good basis for sustainable development and implementation of new strategies.

The first real attempt for a practical transition to an innovative economic model was the state's "Strategy of Industrial and Innovative Development for 2003-2015" (SIID). The implementation of the SIID gave some impetus to increased investment activity within the country. The country was faced with new directions of development, such as the large-scale development of a huge number of investment projects, the opening of new production facilities, and the creation of new job places in all regions and sectors of the economy. The first signs of success with the SIID implementation, was the stimulation of development in the so-called "disruptive projects", including an ambitious state program, "40 corporate leaders of Kazakhstan". The implementation of projects and a strong growth of Kazakhstan's economy continued during the global financial crisis, until the end of 2009, thanks to a successful world market condition, and a timely and accurately developed anti-crisis program of the Government.

However, over the eight years of the SIID, there was no significant qualitative changes in the economy of Kazakhstan, and no preservation of industry or foreign trade structure that can be confirmed by official statistics. Even so, exports of mineral resources in early 2009 amounted to 73-74\% of the total exports, while the share of mining in regards to total industrial production was more than $60 \%$. There was no strengthening of any real innovation, however, given the early termination of the SIID and defiance in regard to the 40 corporate leaders program. As previous heads of the Aktobe oblast business and industry department, we know that many investment projects in Kazakhstan regions had weak technical and economical justifications. These projects were more focused on the large-scale attraction of investments than on market demands and existing risks, and became uncompetitive immediately after the termination of public support.

In some regions (without the involvement of leaders), homogeneous productions have become redundant because of the desire to attract investment for projects at any cost. This has created unnecessary competition for products that already have low demand in the domestic market. The authors, as well as other researchers, have considered these and other costs of inefficient innovative developments reported in the above mentioned papers (Galstyan, 2003; Yvitsa, 2004; Yvitsa, 2005; Steblyakova, 2011). Additionally, in 2010, expenditure on technological innovation in Kazakhstan, overall amounted to 235.5 billion tenge, which is only $26.6 \%$ of the total innovative cost of enterprises for the purchase of machinery and equipment. This compares to research and development of new products, methods production (transfer), and new production processes, which received only $11.3 \%$.

Such a structure of cost allocation for innovation is characteristic of countries with low scientific potential. In western European countries, $80 \%$ of expenditure is allocated for innovation, with more spent on research and development. Differences in approaches undertaken in Kazakhstan and other countries are given in Table 1. These show the predominance of the state strategic planning and forecasting in Kazakhstan, as compared to the more pragmatic foreign models. 


\begin{tabular}{|c|c|}
\hline Foreign countries & Kazakhstan \\
\hline \multicolumn{2}{|c|}{$\begin{array}{l}\text { The predominance of some conceptual approaches in the general strategy of development } \\
\text { for } 2001-2010 .\end{array}$} \\
\hline $\begin{array}{l}\text { Main models, implemented in foreign } \\
\text { countries: development of human capital } \\
\text { assets; innovative ventures; the introduction of } \\
\text { corporate management; and industrial } \\
\text { development. }\end{array}$ & $\begin{array}{l}\text { State strategic planning and forecasting: } \\
\text { Kazakhstan-2030; SIID; "disruptive projects"; } \\
40 \text { corporate leaders, and similar. }\end{array}$ \\
\hline \multicolumn{2}{|c|}{ Crisis bailout plan for 2008-2011. } \\
\hline Financial stability, and control of inflation. & $\begin{array}{l}\text { The realization of the SP FIID; "Business Road } \\
\text { Map-2020", and similar; economic growth } \\
\text { stimulation; micromanagement in the real } \\
\text { sector, and similar. }\end{array}$ \\
\hline \multicolumn{2}{|c|}{ Long-term strategy for the teens of the XX1 century } \\
\hline $\begin{array}{l}\text { Reindustrialization, the preparation for } \\
\text { industrial revolution, and similar. }\end{array}$ & $\begin{array}{l}\text { SSP Kazkahstan-2020; Social modernization; } \\
\text { Concept of Universal Labor Society, } \\
\text { Kazakhstan 2050: Development strategy, and } \\
\text { similar. }\end{array}$ \\
\hline
\end{tabular}

Source: Authors

It is seen from the comparison of approaches that the state, with its inherent functions, is an active subject of the modern market economy: economic, social, administrative, and other similar mechanisms.

1. State-owner: generates the sector of public enterprises and national companies, the management of which is part of its duties.

2. State-enterprise: participates in national and other high-risk projects, using its existing assets, including public and private partnerships, and manages its own or joint businesses;

3. State administrator: coordinates and controls the activities of all economic players, including its own business, and that of the public sector of the national economy; and

4. State corporation: creates conditions for acceptable activities for all economic players, directing them to form the Universal Lobar Society or a welfare group.

Subsequently, the Kazakhstan practice had confirmed the complexity of innovation development and identified inefficiencies in transitioning to an innovative economy as initially elected.. Accordingly, during 2009 - 2010 the Government adopted swift action to change this situation in terms of the most critical areas and points of application. A more thorough analysis of the causes and effects impeding economic development was conducted. The failure in the industrial sector was considered to be the main deterrent in transitioning to an innovative economic model. The reason for adopting a new state program of innovative development was based on rapid industrialization, which was originally about implementing more effective ways for the state to regulate innovative processes.

\section{Innovative activity in Kazakhstan}

Since the adoption of the policy of industrial and innovative development in 2003, Kazakhstan, at year-end 2012, achieved the maximum of growth in the main innovation indicators. This positive trend 
CBU INTERNATIONAL CONFERENCE ON INNOVATION, TECHNOLOGY TRANSFER AND EDUCATION

depended largely on successful implementation of the State Program of Forced Industrial-Innovative Development of Kazakhstan up until 2014.

\section{Business innovative activity}

In 2012, compared to 2003 , the share of innovative activity enterprises increased from $2.1 \%$ to $7.6 \%$.

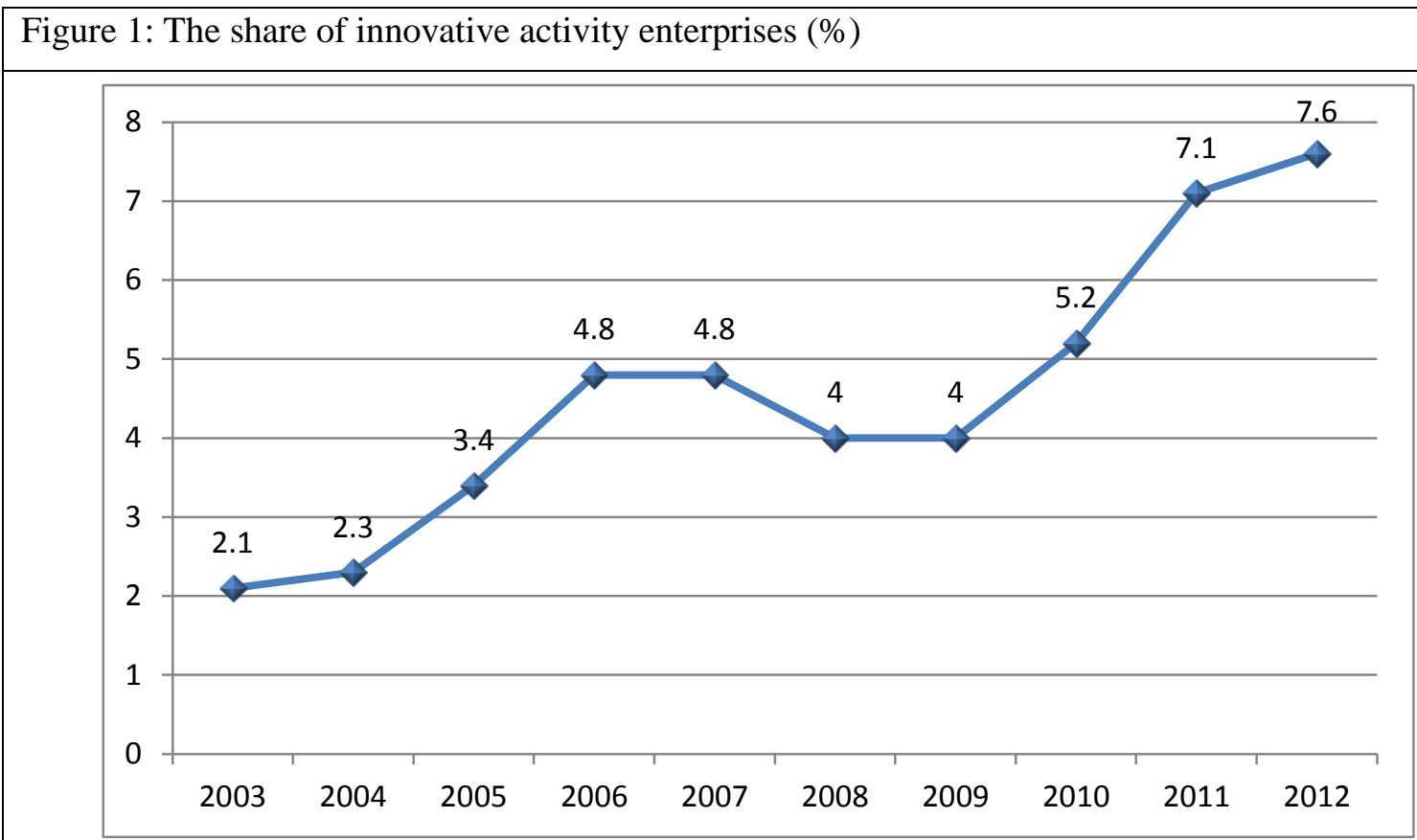

Source: http://www.stat.gov.kz

For comparison, the share of innovative activity enterprises in the US is about $50 \%$, while among the countries of the European Union, Germany has the highest rate (79\%), compared to Sweden $(60 \%)$ and Finland (58\%). The average performance for European Union countries reaches approximately $53 \%$.

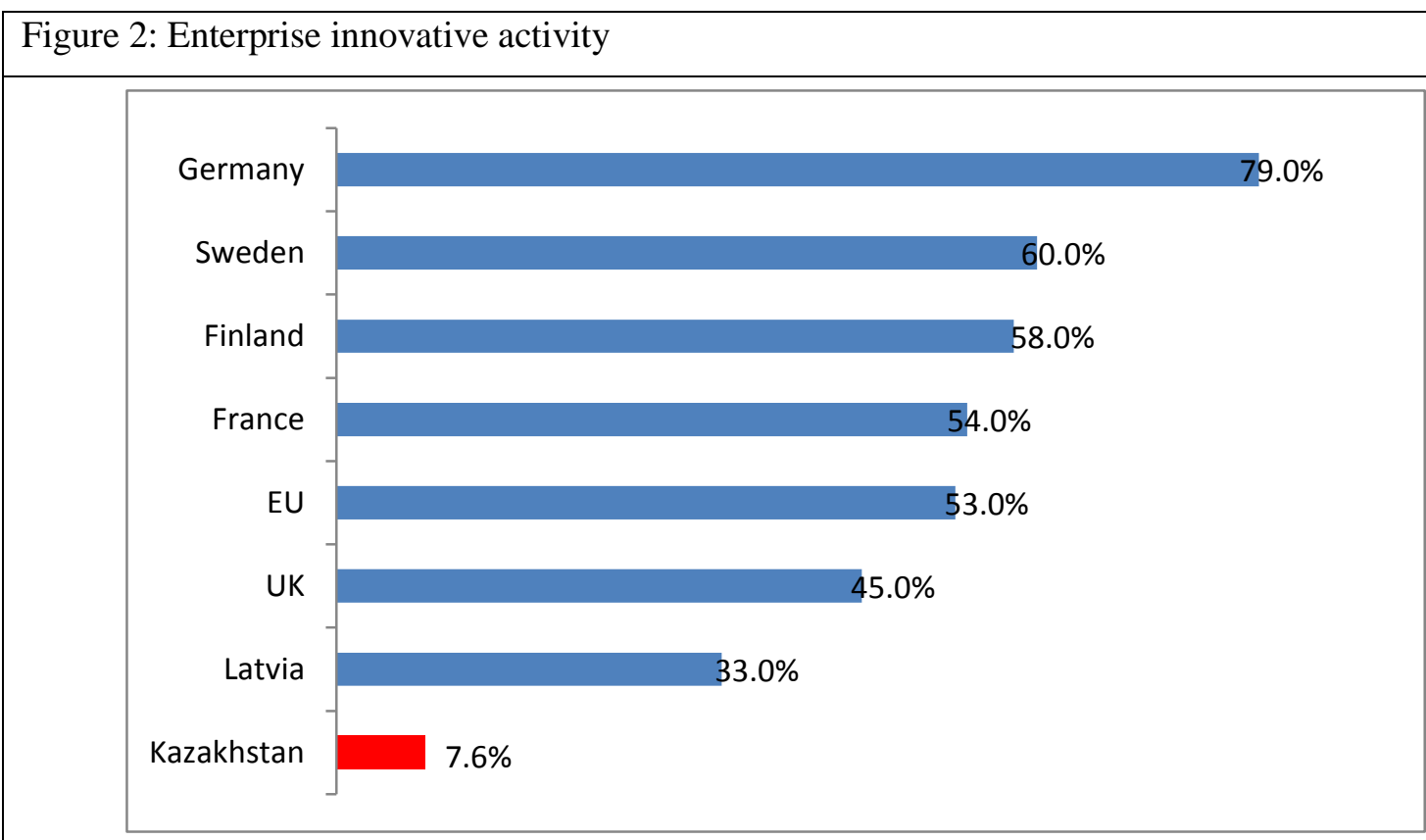

Source: Eurostat Pocketbooks (2013) 


\section{The volume of domestic expenditure on research and development}

Expenditure on research and development (R\&D) is one of the main indicators of innovation at the "input".

Analysis of key indicators of innovative activity is given in Table 2 .

Table 2: Main indicators of innovative activity

\begin{tabular}{|c|c|c|c|c|c|c|}
\hline Indicators & 2008 & 2009 & 2010 & 2011 & 2012 & $\begin{array}{c}2012 \text { as } \\
\% \text { of } \\
2008\end{array}$ \\
\hline $\begin{array}{l}\text { Transfer costs for } R \& D \text {, mln. } \\
\text { tenge }\end{array}$ & 34761.6 & 38988.7 & 33466.8 & 43351.6 & 51253.1 & 147.4 \\
\hline in \% to GDP & 0.22 & 0.23 & 0.15 & 0.16 & 0.17 & 77.3 \\
\hline $\begin{array}{l}\text { Number of enterprises having } \\
\text { R\&D }\end{array}$ & 421 & 414 & 424 & 412 & 345 & 81.9 \\
\hline $\begin{array}{l}\text { Number of employees } \\
\text { involved in } R \& D \text {, persons }\end{array}$ & 16304 & 15793 & 17021 & 18003 & 20404 & 125.1 \\
\hline $\begin{array}{l}\text { Enterprise assets, in R\&D } \\
\text { mln.tenge. }\end{array}$ & 19177 & 22003 & 22811 & 29527.5 & 37950.6 & 197.9 \\
\hline in \% by total volume of assets & 0.25 & 0.22 & 0.20 & 0.24 & 0.27 & 109.8 \\
\hline
\end{tabular}

Source: http://www.stat.gov.kz

The table shows that transfer costs for $R \& D$ increased by $47.4 \%$ in the period 2008-2012, with transfer costs in 2012 equating to 51.3 billion tenge. The R\&D as a percentage of the country's GDP, rated as $0.22 \%$ in 2008 , and then $0.17 \%$ in 2012 , showing a $22.7 \%$ reduction in this factor and a decline in domestic expenditure for R\&D during this period.

With regard to organizations involved in the $\mathrm{R} \& \mathrm{D}$, there are negative trends for 76 organizations. In 2008 there were 421 organizations engaged in research, whereas in 2012 this number was 345 . It should be noted that in 2012, the number of employees involved in R\&D was $25.1 \%$ higher than that of 2008 .

Based on the analysis of institutional changes in Kazakhstan, we have identified the main reasons for the reduced effectiveness of the innovation processes in Kazakhstan, and these are schematically shown in Table 3.

Table 3: Reasons for reducing the effectiveness of innovation processes in Kazakhstan

\begin{tabular}{|l|l|l|l|}
\hline \multicolumn{1}{|c|}{ Economic } & \multicolumn{1}{|c|}{ Organizational } & \multicolumn{1}{c|}{ Legal } & \multicolumn{1}{c|}{ Infrastructural } \\
\hline - low scientific-technical and & - lack of interaction & - incomplete & - technology market \\
innovative potential; & between science and & legislative and & underdeveloped; \\
- lack of assets; & production, and between & normative basis for & - information and \\
- adverse terms of crediting; & state and private sectors; & innovative activity, & communication \\
stimulation and & market \\
- high innovation cost; & lack of new forms of & regulation; & underdeveloped; and \\
- low effective demand for & cooperation, and & - defense of rights for & - innovative \\
innovation; & production of complex & intellectual property; & infrastructure \\
- high economic risk for & products; and & and & underdeveloped. \\
innovation; and & - low level regional and & - patent legislation. & \\
- long-term payoff. & world integration. & & \\
\hline
\end{tabular}

Source: Authors 


\section{Innovative enterprise financing}

Economic diversification is a well-established activity of the Kazakhstan government. This is reflected in the global task, set by the State Program of Forced Industrial and Innovative Development. This program provides for the sustainable development of innovation. However, the next decade is expected to see a doubling of oil production, creating a challenging political task to reduce the country's dependence on primary commodities (United Nations Economic Commission for Europe, 2012).

In the first stage, which started in 2010 after a preparatory phase, the state program focused on modernizing production facilities. The second stage, the stage of a new economic creation, was aimed at developing new enterprises in Kazakhstan, involving companies that were world leaders in their sector. The third stage involved the creation of a framework for the future economy through investments in aerospace, biotechnology, information technology, and alternative energy production (Table 4).

Table 4: State Program of Focused Industrial and Innovative Development of the Kazakhstan (SPFIID)

\begin{tabular}{||l|l|}
\hline $\begin{array}{l}\text { Preparatory stage } \\
(2011-2012)\end{array}$ & $\begin{array}{l}\text { Third stage: base formation for "future economy" (2012-2014) } \\
\text { Aerospace, biotechnology, information technology, and alternative energy production }\end{array}$ \\
\hline $\begin{array}{l}\text { Preparatory stage } \\
(2010-2011)\end{array}$ & $\begin{array}{l}\text { Second stage: new economy creation (high labor efficiency) (2011-2014) } \\
\text { The creation of new enterprises with the world's leading companies in certain sectors } \\
\text { of the master plan } \\
\text { Development of measures to stimulate the economy (SEZ development, reducing the } \\
\text { share of oil and gas exports through the export of other commodities, and foreign } \\
\text { investment) }\end{array}$ \\
\hline $\begin{array}{l}\text { Preparatory stage } \\
\text { (2009) }\end{array}$ & $\begin{array}{l}\text { First stage: economy base modernization (material refining efficiency) (2010- } \\
\text { 2014) } \\
\text { The establishment and operation of scheduled national and regional investment } \\
\text { projects } \\
\text { Development of industrial and regional development programs } \\
\text { Development of laws on industrial policy, SEZ }\end{array}$ \\
\hline Sources: Authors &
\end{tabular}

Currently, the complex instruments under state influence aim to achieve the economic level of developed countries that are close to the technological frontier. Strategies must differ from the measures already implemented, to ensure similar effectiveness to that of the more developed countries. This applies to the various tasks assigned to each of the three stages of the development strategy of Kazakhstan. The modernization of existing structures is mainly carried out at the expense of investments. It needs imports and effective use of industrial technologies, including the improvement of the workshop management, organizational innovation, and staff development (United Nations Economic Commission for Europe, 2012).

Initially, booster strategies and measures for developing innovative potential of the economy should dominate in the context of Kazakhstan, which can draw on the second stage of SPFIID, and grow over time. The emphasis here is on creating an enabling environment for innovation that contributes to sustainable and gradual progress on several issues (United Nations Economic Commission for Europe, 2012). 


\section{State financial institutions}

The political stage of SPFIID provides guidelines and a legal framework to develop financial support for innovation within the country. This is a part of the Kazakhstan Strategic Development Plan until 2020 (United Nations Economic Commission for Europe, 2012).

A number of institutions that are involved in financing and modernizing management operates in Kazakhstan. These include institutions that fund investments, attract infrastructure projects, and provide resources for innovation. The most important institutions in this area are discussed below.

The Development Bank of Kazakhstan (DBK) was founded in 2001. It provides financial support to the private sector and government agencies by providing medium- and long-term loans at low interest rates. The Bank focuses on infrastructure projects and crediting industrial enterprises. It is owned by Samruk-Kazyna (United Nations Economic Commission for Europe, 2012).

The purpose of the DBK is to promote sustainable economic growth by providing long-term funding and various financial services in non-extractive industries. Since its formation in 2001, the Bank has considered a total of 180 projects, totaling 10.4 billion US dollars, of which 5.1 billion US dollars were provided by the DBK.

From 2007 to 2011, the Bank's portfolio grew more than three times. The Bank's assets amounted to more than 6 billion US dollars, of which about 2 billion US dollars were singled out as loans. The subsidiary organization, DBK-Leasing, established in 2005, provides short-term and long-term lease financing and participates in the program, "2020 Productivity". Their existing loan portfolio shows significant lending to primary industries, based on raw materials, such as oil refining, energy, metals, and non-metals production, which accounted for nearly two-thirds of the total loan portfolio at the end of the first half of 2011. Lending for transport and logistics also comprises a large amount and represents about $10 \%$ of the Bank's total portfolio.

The DBK plans to become a major source of long-term finance for infrastructure development, strategic investment projects, and export operations. It plays an important role in the implementation of SPFIID. With this state program, the Bank plans to increase the share of lending to the following industries: metal, transport, energy (electricity), chemical and petrochemical, telecommunications, and others.

The Daтu Entrepreneurship Development Fund was created in 1997 to provide financial and nonfinancial support to small and medium-sized enterprises, and to stimulate demand for products and services of these companies. Damu is working at the regional and national levels. With 16 offices across the country, this subsidiary of Samruk-Kazyna tends to be a unifying channel of governmental measures that support entrepreneurship development and small- and medium-sized businesses with 13 financial and 11 non-financial programs. The fund also assists the business environment in general. Damu is currently a financial party of the "Business Road Map 2020", one of the SPFIID activity directions (United Nations Economic Commission for Europe, 2012).

The purpose of the Investment Fund of Kazakhstan (IFK, established in 2003) is to ensure that the industrial and innovation policy in Kazakhstan are included in implementation, and investment projects and financial support is provided for private sector initiatives in non-oil sectors of the economy. The achievement of these goals is provided through direct equity participation in the invested companies (United Nations Economic Commission for Europe, 2012).

The IFC invests in new and existing companies that are engaged in raw material processing and which use new technologies in the development of competitive products. As well, it provides services to other companies. The IFC is also co-financed and involved in the management of investment projects 
in the non-oil sectors of the economy. The fund participates in co-financing overseas investment projects that deal with inititating industrial cooperation between national and foreign companies.

Its current portfolio includes 28 investment projects amounting to 670 million US dollars. The direct participation of IFC makes up 198 million US dollars.

Over the past 10 years, Kazakhstan has adopted a number of measures to create an institutional infrastructure that supports innovation. One involved the creation of the National Innovation Fund (NIF) in 2003, under the Ministry of Industry and New Technologies. The NIF activities include: operation of the Center for Engineering and Technology Transfer (CETT), direct investments in innovative companies, and support to R\&D projects. The NIF is actively involved in promoting innovation through investment in equity share capital, redeeming domestic and foreign venture capital funds, supporting technology parks, and stimulating the development of an innovative culture.

The Fund of Science was established in 2006. The fund is actively operating in the field of information and communication technology (ICT) and space technology, nanotechnology and new materials, biotechnology, renewable energy technology, and nuclear technology. The fund provides loans to scientists who plan to set up a company or sell their findings in the next $3-5$ years. The funding ranges from about 50 thousand to 2 million US dollars. Eleven projects are supported so far, and in mid-2011, three of these started redeeming the funds provided (Table 4).

\begin{tabular}{|l|l|l|l|}
\hline \multicolumn{2}{|l|}{ Table 4: Review of main institutions and their financial instruments } \\
\hline \multicolumn{1}{|c|}{ Financial institutions } & Participation in financing & \multicolumn{1}{c|}{ Loans } & \multicolumn{1}{|c|}{ Grants } \\
\hline $\begin{array}{l}\text { Development Bank of } \\
\text { Kazakhstan }\end{array}$ & $\begin{array}{l}\text { Infrastructure } \\
\text { development, pilot } \\
\text { projects, and industrial } \\
\text { companies }\end{array}$ & $\begin{array}{l}\text { Various programs, micro- } \\
\text { finance, "Business Road } \\
\text { Map 2020", "2020 } \\
\text { Productivity", etc. }\end{array}$ & $\begin{array}{l}\text { R\&D grants for } \\
\text { various aims: } \\
\text { patenting, } \\
\text { technology } \\
\text { Development Fund (Damu) }\end{array}$ \\
\hline $\begin{array}{l}\text { Investment Fund of } \\
\text { Kazakhstan }\end{array}$ & $\begin{array}{l}\text { Various development } \\
\text { projects }\end{array}$ & $\begin{array}{l}\text { acquisition, project } \\
\text { feasibility study, } \\
\text { and R\&D }\end{array}$ \\
\hline National Innovation Fund & $\begin{array}{l}\text { investment projects to } \\
\text { national and foreign venture } \\
\text { funds }\end{array}$ & R\&D grants \\
\hline
\end{tabular}

Souces: Kurmanov at al., 2013

All institutions are currently considering new opportunities to replenish their portfolio of tools. Damu, for example, is working on a guarantee mechanism to assist small and medium enterprises (SMEs) in obtaining financial support from the banking system and have plans to invest in equity share capital. NIF continues its activity on the development of business incubation in technology parks.

For more effective actions, sectoral programs have been adopted in all the 13 priority sectors: mining and metals, machinery, chemical, pharmaceutical, textile and construction, production of construction materials, oil and gas, transport infrastructure, agriculture, space activities, information and communication technologies, and tourism. This involves more than 100 new business support tools. Laws pertaining to the state support of industrial innovation, energy conservation and efficiency have 
been adopted. In addition, laws for creating special economic zones and reducing administrative barriers for business have been developed and adopted (United Nations Economic Commission for Europe, 2012).

Along with the sectoral programs, there are special programs that support the project. These include 1) the forced modernization of the existing and creation of new productions through "2020 Productivity"; 2) a design-targeted, export development and promotion program with "2020 Export"; 3) support and encouragement for foreign direct investment with "Investor - 2020"; and 4) the development of entrepreneurship in the regions with "Business Road Map 2020." Today, forced industrialization is an objective necessity for Kazakhstan. Through rational territorial organization of economic potential, the "Industrialization Map for 2010-2014" will allow the creation of new economic growth centers in the country, and a balanced development of priority sectors (Koshanov, 2012; Dnishev, 2012; Saktaganova, 2011).

\section{The develpment of innovation support system of the enterprise}

To ensure further innovative development of enterprises, the following is recommended.

The development of an effective system for technology commercialization. Commercialization of technologies should be linked directly to the practical application of scientific and technological activities, in order to introduce into the market either new or improved products, and processes and services, that have a positive economic effect.

A systematic approach to commercializing technology will give a significant impetus for a rapid introduction of scientific and technical activities in the economic cycle. This will eventually allow the state to create new jobs, to return to the budget through tax revenue, invest in research and development work, and improve the overall competitiveness of Kazakhstan in the global technology market.

To create a normative legal base for the development of a system for intellectual property and commercialization in the Republic of Kazakhstan, the interests of all stakeholders in intellectual property and commercialization should be taken into account, to ensure investments are stable and secure. This measure will allow research institutions to participate in all forms of intellectual property and commercialization, and likewise for researchers working in public research institutions. As well, it will allow them to manage and own a share of the stocks in an innovative company. This would reduce the risk of scientific unities creating their own intellectual-property based business.

In particular, according to the experience of European countries, state support for the use of the commercial potential of research institutes and universities, stimulates and motivates scientists and institutions to commercialize their knowledge and technology. The continuous transfer of knowledge from the public sector to the private should be developed. It is necessary to arrange measures to recognize domestic patents abroad, develop a system of intellectual property for implementation into the economic circulation, and develop a state system of intellectual property valuation.

It is also necessary to create a system of information exchange - a state created network of institutions for innovative development, to support innovative projects at all stages. As a part of such a system of information exchange, the mechanism of forwarding on information, which promises innovative projects among institutions of innovative development, should be established. An information exchange system should also be an effective tool of "linking" the research and development with the business, resulting in the formation of new companies based on the results of applied research.

Development of national human resources and accumulation of competences in the field of technology commercialization. To build competencies in the field of technology, a development 
priority would be to provide commercialization training to staff supporting the commercialization process and their primary beneficiaries.

The development of human resources is required for successful commercialization. Training, exchange of experience, and targeted outsourcing of professional advice will play a central role in creating a sustainable system of technology commercialization in Kazakhstan. In this regard, it is necessary to encourage local experts to participate in various programs that improve competence in the field of commercializing innovation and to visit foreign structures of technologies for best practice in commercialization.

The stimulation of enterprise innovation activity. The transition of Kazakhstan's innovation system from a model driven by the state to a sustainable system driven by the private sector is necessary to reduce administrative barriers and tax incentives, provide access to finance, create innovation clusters, develop the business environment, and to create demand for innovation.

The reduction of administrative and technical barriers, together with improved access to finance will contribute to the emergence of a large number of innovative companies.

The openness of the domestic markets will lead to an increased access to global knowledge and technologies. In this case, the transfer of advanced knowledge and technologies could be implemented through the creation of an enabling environment and incentive tools, including the following important directions:

- the involvement of foreign innovative companies of small- and medium-sized, and the creation of joint ventures among these;

- the maximum use and attraction of scientific potential from fellow scientists who are successfully working in foreign research institutions; and

- disclosure of foreign patents and licenses with the transfer of advanced technologies to improve the competence of local specialists.

In order to better promote Kazakhstan's high-technology products in international markets, it is necessary to strengthen regular interaction among stakeholders (e.g. the export-oriented hightechnology and innovative enterprises and companies; joint-stock company "National Agency for Technological Development"; JSC with their "Damu Entrepreneurship Development Fund"; and JSC with their "National Agency for Export and Investment").

The reduction of administrative barriers and tax incentives. Today, Kazakhstan functions under the principle of tax legislation unity, which provides a single regime for all businesses, regardless of the innovative component of their products.

At the same time, innovative companies are in need of an unprecedented legal regime that will minimize administrative barriers.

In order to develop possible administrative and tax incentives for innovation, the following actions are needed:

- explore the possibility of developing and implementing mechanisms for the promotion of enterprises that work in the legal field; and

- consider the desirability of introducing a special tax regime to facilitate the conditions for innovative enterprises during the first five years of development.

Financial inclusion. Financial inclusion remains a key limiting factor for the development of entrepreneurship in Kazakhstan. This is due to the reluctance of the banking sector to finance risky and innovative projects. In particular, these are projects, belonging to small- and medium-sized businesses, which, in most cases, can provide only limited resources to secure a loan. 
In our opinion, for these purposes, it is necessary to work through the following measures:

- increase the issuance of microcredits and small grants to promote pilot implementation of capacities and entrepreneurial initiatives;

- develop financing of equity instruments and tools, aimed at financing the early stages of development of the company; and

- develop corporate venture capital, by encouraging large companies, including foreign companies, to acquire shares in the new innovative companies.

The creation of innovative clusters will increase the innovative activity of business entities, as well as lead to the emergence of synergies. For example, form clusters of participating companies, which are more likely to create new products than single enterprises. In this case, the activity of enterprises within the cluster can overlap and complement each other. The formation of innovation clusters, simultaneously, promotes interchange between related industries and fierce competition within industries.

The formation of the demand for innovation. When building an effective national innovation system, the attention should be focused on implementing measures that increase the demand for innovation. Most countries that are rapidly developing their innovative systems do not succeed, due to poor demand for innovation.

As shown from international practice, central to the system of national innovation are businesses with their own capacity for carrying out research and development that enables them to innovate successfully.

Today, a weak demand is the key constraint to the promotion of innovation within the country. The formation of demand for innovation should be provided by the state through regulatory measures and incentives.

The development of innovative infrastructure. The activity of innovative infrastructure should focus on providing the necessary financial, methodological, and information support at all stages of the innovation process. It should also create and promote new developments that provide advanced scientific development, and introduce high-technology industries. The main elements of the innovative infrastructure are: a special economic zone, "Park of innovative technologies"; regional technical parks; venture capital funds; industrial design offices; and international technology transfer centers.

By interacting with each other, these elements of innovative infrastructure will provide an integrated system of support for innovation at all stages of implementation, and this will allow companies to:

- maximize capture of innovative subjects with tools supported by the state;

- establish an effective system of commercialization and promotion of innovation, based on national scientific research; and

- establish a system of transfer, localization and distribution of the necessary foreign technologies.

\section{Conclusion}

Integrative processes provide an opportunity for Kazakhstan to expand its markets and increase its capacity for innovation. Competitive pressure creates a huge incentive for Kazakhstan enterprises to innovate. To take full advantage of these opportunities, it is necessary to make effective policy measures to support further modernization and diversification of the economy.

The questions regarding innovative processes, management improvement, and innovative achievements are now becoming more relevant. They require the participation of the various layers of 
Kazakh society. At the same time, as evidenced by the latest Kazakhstan experience, the coordinating and controlling (combining) role of the state in this area is becoming increasingly important and serves an inherent function.

\section{References}

Aktobe Regional State University. (2011). V International scientific conference Forced industrialization and innovative development of economy in Kazakhstan: strategy and mechanisms of implementation. Aktobe: ASU after K. Zhubanov.

Astana Economic Forum. (2012). Innovation business - a way to competitive economy: VII Innovative congress in the frames of V Astana Economic Forum: Collection of articles of VI Innovative congress speakers. Karaganda, LLP, Arko: AEF.

Dnishev, F. M. (2012). Technological modernization and innovative development in Kazakhstan. ENU Messenger, 1, 16-31.

Eurasion National University. (2011). Management of innovative economy. In the Republican scientific practical seminar. Astana: ENU after L.N. Gumilyov.

Eurostat Pocketbooks (2013). Science, Technology and Innovation in Europe (2013 edition). Retrieved from http://ec.europa.eu/eurostat/documents/3930297/5969406/KS-GN-13-001-EN.PDF

Galstyan, K.G. (2003). The orients of modern innovative policy and its mechanisms. St. Petersburg: SPYEF.

Koshanov, A. K. (2012). Industrial and innovative challenges of globalization and factors of a high technology competitive national economy creation. ENU Messenger, 1, 6-16.

Kurmanov, N., Kabdullina, G., Karbetova, Z., Tuzubekova, M., Doshan, A., \& Karbetova, S. (2013). Motivation of employees' labor activity in oil and gas companies in Kazakhstan. World Applied Sciences Journal 26 (12), 1556-1561.

Nazarbayev, N. A. (1997, October 10). 2030 Prosperity, security and ever growing welfare of all the nation. Address of the President of the Republic of Kazakhstan to the People of Kazakhstan. Retrieved from http://www.akorda.kz.

Nazarbayev, N. A. (2005, February 18). Kazakhstan on the Road to Accelerated Economic, Social and Political Modernization. Address by the President of the Republic of Kazakhstan, Nursultan Nazarbayev, to the People of Kazakhstan. Retrieved from http://www.akorda.kz.

Nazarbayev, N. A. (2012, January 28). Socio-Economic Modernization as Main Vector of Development of Kazakhstan. Address by the President of the Republic of Kazakhstan, Nursultan Nazarbayev, to the People of Kazakhstan. Retrieved from http://www.akorda.kz.

Nazarbayev, N. A. (2012, September 6). Kazakhstan on the road for social knowledge. Interactive lecture of the President of the Republic of Kazakhstan, Nursultan Nazarbayev, in Nazarbayev University. Retrieved from http://www.akorda.kz.

Nurlanova, N. K. (2011). Regional innovation policy and its realization mechanisms. ENU Messenger, 4, 96-104.

Saktaganova, G. S. (2011). Clusters in innovative economy development. ENU Messenger, 3, 211-217.

Steblyakova, L. P. (2011). Kazakhstan economy modernization: new opportunities and perspectives. In XX1 century State management: traditions and innovations. International conference Part 1. Moscow: Moscow University.

United Nations Economic Commission for Europe. (2012). Innovation performance review of Kazakhstan. Retrieved from. http://www.unece.org/publications/oes/welcome.html.

Yvitsa, N. V. (2004). Innovative development and innovative potential of the region. Scientific practical conference. Akrobe: AEIS.

Yvitsa, N. V. (2005). Prospects for the use of natural resources in Aktobe region in terms of economic modernization. In the International scientific practical conference: Strategy of industrial innovative development of the country - the program of future. Aktobe: AEIS.

Yvitsa, N. V. (2012). The formation of innovation economy in Kazakhstan and foreign experience. ENU Messenger, 1, 4452. 